\title{
OPTIMALISASI PEMBERDAYAAN KADER PKK TERHADAP PENINGKATAN KERAJINAN LIMBAH PLASTIK
}

\author{
Estrin Handayani $^{{ }^{*}}$, Nufikha Falyauma ${ }^{2}$, Dhian Dwi Hartini ${ }^{1}$, \\ Sulistiyani Purna Sari ${ }^{1}$, Seno Marijanto ${ }^{1}$ \\ ${ }^{1}$ Program Studi Keperawatan, Fakultas Ilmu Kesehatan, UNIMMA \\ ${ }^{2}$ Program Studi Farmasi, Fakultas Ilmu Kesehatan, UNIMMA \\ Email: *estrinhandayani@ummgl.ac.id
}

\begin{abstract}
The activities to optimize the empowerment of PKK cadres include 15 housewives who initially did not have productive activities, now they had skill in making crafts made from plastic waste. The program that has been implemented is the use of plastic waste into handicrafts as a means of entrepreneurial-based creative economy. This program is very helpful in maintaining the balance of the environment in an ecological manner. Preserving the environment is a very important factor today. Many natural disasters are caused due to damaged environment. PKK provides simple counseling so that the environment is not damaged and prevents contamination of water sources, carries out plastic waste management using handicrafts. The method used in this activity is Participatory Rural Appraisal, which is an approach method in the process of empowering and increasing community participation by emphasizing community involvement in all activities carried out. The purpose of this Community Service activity is to reactivate community cadres in managing waste into crafts based on creative economy entrepreneurship. The results of this event were attended by 15 PKK members, and 3 small groups were produced based on the raw materials used with craft management creations.
\end{abstract}

Keywords: Crafts ; Garbage Waste; PKK Cadres; Plastic Waste

\begin{abstract}
Abstrak: Kegiatan optimalisasi pemberdayaan kader PKK ini meliputi 15 orang Ibu Rumah Tangga yang awalnya tidak mempunyai kegiatan produktif, sekarang telah terampil dalam membuat kerajinan berbahan baku limbah plastik. Program yang telah dijalankan berupa pemanfaatan limbah plastik menjadi kerajinan tangan sebagai sarana ekonomi kreatif berbasis wirausaha. Program ini sangat membantu dalam menjaga keseimbangan lingkungan secara ekologis. Menjaga kelestarian lingkungan menjadi faktor yang sangat penting dewasa ini. Banyak bencana alam yang disebabkan karena lingkungan yang rusak. PKK memberikan penyuluhan sederhana agar lingkungan tidak dirusak dan mencegah pencemaran sumber air, melaksanakan pengelolaan sampah plastik dengan pemanfaatan kerajinan tangan. Metode yang digunakan dalam kegiatan ini adalah Participatory Rural Appraisal yaitu metode pendekatan dalam proses pemberdayaan dan peningkatan partisipasi masyarakat dengan menekankan pada keterlibatan masyarakat dalam semua kegiatan yang dilaksanakan. Tujuan dilakukan kegiatan Pengabdian ini adalah untuk mengaktifkan kembali pengkaderan masyarakat dalam mengelola limbah sampah menjadi kerajinan yang berbasis wirausaha ekonomi kreatif. Hasil pengadian ini dihadiri oleh 15 anggota PKK Dusun Wonosuko, dan dihasilkan 3 kelompok kecil berdasarkan bahan baku yang digunakan dengan kreasi pengelolaan kerajinan.
\end{abstract}

Kata Kunci: Kader PKK; Kerajinan; Limbah Plastik; Limbah Sampah 
Jurdimas (Jurnal Pengabdian Kepada Masyarakat) Royal

Vol. 4 No. 2, Mei 2021, hlm. 173 - 180

DOI: https://doi.org/10.33330/jurdimas.v4i2.955

Available online at https://jurnal.stmikroyal.ac.id/index.php/jurdimas

\section{PENDAHULUAN}

Kabupaten Magelang sebagai salah satu Wilayah yang ada di Jawa Tengah dengan timbunan sampah 85 ton/hari dan jumlah terangkut adalah 52,5 ton per hari, dengan sumber sampah berasal dari pemukiman dan pasar tradisional yang terdiri dari sampah organik dan sampah anorganik dengan sampah tersebut akan bermuara ke Tempat Pembuangan Akhir (TPA) yang beroperasi di wilayah Jawa Tengah di wilayah Banyuurip Tegalrejo Magelang dan TPA memiliki umur operasional yang terbatas, sehingga diperlukan suatu rencana pemanfaatan sampah TPA yang paling sederhana yang dapat dilakukan melalui 3R baik sampah organik maupun sampah anorganik (Rodiah, Lusiana, \& Agustine, 2016).

Salah satu yang kini menjadi permasalahan di tengah-tengah masyarakat terkait kenyamanan lingkungan hidup adalah sampah, baik sampah hasil rumah tangga maupun sampah pada umumnya (Filmawada, Hardika, \& Sucipto, 2018). Karena sampah merupakan hal yang pasti dihasilkan oleh makhluk hidup di dalam kehidupan sehari-hari. Mengingat akan hal itu maka ibu rumah tangga di dalam kepengurusan PKK Dusun Wonosuko Tegalrejo Magelang mencoba menyikapi gejalagejala yang timbul di tengah-tengah masyarakat kami dengan cara menanamkan rasa keperdulian akan kebersihan dan kenyamanan terhadap lingkungan sekitar.

Hal tersebut disikapi oleh seluruh lapisan warga yang ada di dusun Wonosuko yang di pelopori oleh Tim Penggerak PKK, karena kami sadar persoalan tersebut tidak mungkin dapat tercipta tanpa adanya keterlibatan dari semua pihak yang ikut berpartisipasi untuk penanganan masalah tersebut yang kini menjadi tujuan pemerintah kabupaten Magelang setempat juga, khususnya pemerintah Desa Tegalrejo Magelang, karena kami yakin dengan kebersamaan dan kegotong-royongan, permasalahan seberat apapun akan terasa ringan. Begitupun sebaliknya, dengan membiarkan gejala-gejala yang timbul pada masyarakat maka dampak kerugiannya akan semakin meluas, karena semakin hari semakin bertambah sampah yang dihasilkan oleh masyarakat karena populasi yang semakin meningkat (Sugiarto \& Mutiarin, 2017).

Kader PKK yang ada di dusun wonosuko terdiri dari 15 orang, dalam hal ini PKK memanfaatkan jalur pendidikan non-formal. Program yang akan dijalankan berupa pemanfaatan limbah plastik menjadi kerajinan tangan sebagai sarana ekonomi kreatif berbasis wirausaha. Program ini sangat membantu dalam menjaga keseimbangan lingkungan secara ekologis. Menjaga kelestarian lingkungan menjadi faktor yang sangat penting dewasa ini. Banyak bencana alam yang disebabkan karena lingkungan yang rusak. PKK memberikan penyuluhan sederhana agar lingkungan tidak dirusak dan mencegah pencemaran sumber air, melaksanakan pengelolaan sampah plastik dengan pemanfaatan kerajinan tangan. Masyarakat di Dusun Wonosuko mayoritas bermata pencaharian sebagai petani sekitar 20\% sebagai PNS 5\%, Karyawan swasta $45 \%$ dan Pedagang $30 \%$.

\section{METODE}

Metode yang digunakan dalam kegiatan ini adalah Participatory Rural Appraisal yaitu metode pendekatan dalam proses pemberdayaan dan peningkatan partisipasi masyarakat 
Available online at https://jurnal.stmikroyal.ac.id/index.php/jurdimas

dengan menekankan pada keterlibatan masyarakat dalam semua kegiatan yang dilaksanakan (Setianingsih, Setyowati, \& Siswidiyanto, 2019). Pada metode ini didasarkan pada proses belajar mandiri dimana pada kegiatan terdapat tutor yang berfungsi untuk memandu jalannya kegiatan. Adapun tahapan kegiatan yang dilakukan yaitu :

Perencanaan, pada tahap ini dilakukan kegiatan berupa:

a. Peninjauan/Survey lokasi dan permohonan ijin kepada Mitra

b. Perumusan masalah

Berdasarkan hasil diskusi dengan Ketua PKK dusun Wonosuko, kepala dusun Wonosuko dan tokoh masyarakat, akan memanfatkan limbah plastik untuk beragam kerajinan serta perintisan bank sampah.

c. Pemecahan masalah

Pada tahap ini disusun jenis kegiatan yang akan dilakukan berserta dengan materi pengabdian sesuai dengan permasalhan yang dihadapi masyarakat.

d. Penyusunan jadwal kegiatan dan pembagian tugas dengan tim pelaksana. Pembagian tugas berdasarkan keahlian pelaksana. Penyusunan jadwal kegiatan dilakukan dengan memperhatikan solusi dari permasalahan masyarakat.

e. Penyiapan materi kegiatan berupa materi

1) Manfaat limbah plastik untuk Ekonomi kreatif

2) Macam-macam kerajinan dari limbah plastic

3) Pemasaran hasil produk Penyiapan ini didasarkan pada permasalahan yang telah digali. Pada tahap ini juga disusun metode yang akan digunakan pada kegiatan pengabdian.
Pelaksanaan, tahap pelakasanaan terdiri dari:

a. Sosialisasi

Sosialisasi dilakukan kepada mitra yaitu:

1) Kepala Dusun Wonosuko

2) Ketua PKK Dusun Wonosuko

3) Kader PKK dari 4 RT, dusun Wonosuko

b. Penyuluhan

Penyuluhan dilakukan dengan memberikan materi:

1) Manfaat limbah plastik untuk Ekonomi kreatif

2) Macam-macam kerajinan dari limbah plastic

3) Pemasaran hasil produk

c. Pelatihan

Pelatihan dengan mengundang narasumber

Adapun kelengkapan yang wajib dibawa oleh peserta pelatihan, yaitu:

1) Membawa limbah tas kresek yang sudah dicuci bersih dan dikeringkan serta gunting

2) Setiap peserta praktek membuat kerajinan dari limbah plastik

3) Mendiskusikan kesinambungan kegiatan ketrampilan

4) Mendiskusikan bahan baku dan pemasaran

Pendampingan, pendampingan dilakukan setelah pelatihan, latihan bagi yang belum bisa membuat kerajinan limbah plastik akan dilakukan latihan secara berkesinambungan dengan cara mendampingi ibu-ibu PKK dalam latihan pembuatan kerajinan limbah plastic.

Pelaporan dan Tindak Lanjut, Pelaporan dilakukan setelah kegiatan selesai dan juga dilakukan penyusunan artikel yang akan dipublikasikan. Pada tahap akhir dilakukan evaluasi untuk menilai apakah semua proses kegiatan sudah dilaksanakan atau tidak. Evaluasi dilakukan untuk menilai keberhasilan 
Jurdimas (Jurnal Pengabdian Kepada Masyarakat) Royal

Vol. 4 No. 2, Mei 2021, hlm. 173 - 180

ISSN 2614-7912 (Print)

DOI: https://doi.org/10.33330/jurdimas.v4i2.955

Available online at https://jurnal.stmikroyal.ac.id/index.php/jurdimas

dalam pemanfaatan limbah plastik.

\section{PEMBAHASAN}

Hasil kegiatan Pengabdian Pada Masyarakat Terpadu (PPMT) ini telah dilakukan pada bulan Agustus sampai dengan November 2020. Beberapa program kegiatan yang dilakukan terdiri dari; Perencanaan, Pelaksanaan, Pendampingan Mandiri dan Tindak lanjut (evaluasi). Berikut pemaparan kegiatan PPMT ada pada Gambar 4:

\begin{tabular}{|c|c|c|c|c|c|c|c|c|c|c|c|c|c|c|c|}
\hline \multirow[t]{2}{*}{ A } & B & C & & E & $F$ & $H$ & 1 & j & $K L$ & - $M$ & N & 0 & $P Q$ & $R$ & $S$ \\
\hline & KegiatanPPMT & \multicolumn{14}{|c|}{\begin{tabular}{l|l} 
& Pelaksanaan (Jam) \\
\end{tabular}} \\
\hline No & ProgramKegiatan & Nama & & $M 2$ & & & & & & 何| & & 11 M12 & $2 \mathrm{M13} \mid \mathrm{M} 14$ & 415 & \\
\hline \multicolumn{16}{|c|}{ PERENCANAAAN (44) } \\
\hline & Surveike lokasipengabdian & Ketua dan anggota & 3 & & & & & & & & & & & & \\
\hline & Koordinasi dengan kepala dusun dan ketua mitra & Ketua dan anggota & 3 & & & & & & & & & & & & \\
\hline 3 & Waw ancara kepada kader pkk wonosuko & \begin{tabular}{|c|} 
Seno \\
\end{tabular} & \begin{tabular}{|l|l|}
5 \\
\end{tabular} & 5 & & & & & & & & & & & \\
\hline 4 & Diskusiuntukidentifikasimasalah & Dhian & 5 & 5 & & & & & & & & & & & \\
\hline 5 & Penyusunan proposal bersama DPL & Ketua dan anggota & & 2 & 2 & & & & & & & & & & \\
\hline 6 & Membuat roadmap kegiatan & Pilka & & 2 & 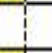 & & & & & & & & & & \\
\hline 7 & KonsultasilFGD mengenai pengelolaan sampah & Nina & & 4 & $\overrightarrow{4}$ & & & & & & & & & & \\
\hline 8 & Perencenaan kegiatan & Seno & & 2 & 2 & & & & & & & & & & \\
\hline \multicolumn{16}{|c|}{ PELAKSANAAN (92) } \\
\hline 9 & Mengikut kegiatan kader dan dokumentasi & Ketua dan anggota & & 4 & & & & & & & & & & & \\
\hline 10 & Sosialisasikepada kader pkk dan masyarakat & Ketua dan anggota & & & $\overrightarrow{4 !}$ & & & & & & & & & & \\
\hline 11 & Pembuatan banner & Piliz & & & 7 & 4 & & & & & & & & & \\
\hline 12 & Diskusimengenai pembuatan kerainan & Pilla & & & $\overrightarrow{4 !}$ & & & & & & & & & & \\
\hline 13 & Penyuluhan pentingnya organisasikader pkk & Seno & & & 4 & & & & & & & & & & \\
\hline 14 & Penguatan kader pkki struktur organisasi & Dhian & & & $\overrightarrow{4 !}$ & & & & & & & & & & \\
\hline 15 & Penyuluhan bahaya limbah plastik & Nina & & & 4 & & & & & & & & & & \\
\hline & Penyuluhan pemanfaatan limbah plastik & Ketua dan anggota & & & 4 & & & & & & & & & & \\
\hline & Pembuatan kerajinan tangan tahap 1 & Dhian & & & & 4 & 4 & 4 & & & & & & & \\
\hline & Pembuatan kerainan tangan tahap 2 & Ketua dan anggota & & & & & & & $\begin{array}{ll}4 & 4\end{array}$ & 44 & & & & & \\
\hline & Perencanaan pemasaran & Nina & & & & & & & & & 4 & & & & \\
\hline & FGD Pemasaran produk & Dhian & & & & & & & & & & 3 & 3 & & \\
\hline & Pendampingan & Ketua dan anggota & & & & & & & & & & 5 & 5 & & \\
\hline & Pembuatan video dokumentasi & Plika & & & & & & & & & & 5 & 5 & & \\
\hline & Pembuatan artikel ilmiah & Ketua dan anggota & & & & 3 & 3 & & & & & & & & \\
\hline \multicolumn{16}{|c|}{ LAPORAN DAN TINDAKLAN LUUT (24) } \\
\hline & Pembuatan laporan akhir & \begin{tabular}{|l|} 
Ketua dan anggota \\
\end{tabular} & & & & & & & & & & & 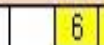 & 6 & 6 \\
\hline & Publikasi artikel ilmiah & Ketua dan anggota & & & & 2 & & & & & & & & & \\
\hline & Pubblikasivideo dimedia sosial & Seno & & & & & & & & & & & & & 2 \\
\hline & Publikasikegiatan di media cetak & Nina & & & & & & & & & & & & & 2 \\
\hline
\end{tabular}

Gamab 4. Jadwal Perencanaan Kegiatan PPMT 
Jurdimas (Jurnal Pengabdian Kepada Masyarakat) Royal

Vol. 4 No. 2, Mei 2021, hlm. 173 - 180

ISSN 2614-7912 (Print)

DOI: https://doi.org/10.33330/jurdimas.v4i2.955

ISSN 2622-3813 (Online)

Available online at https://jurnal.stmikroyal.ac.id/index.php/jurdimas

\section{Pelaksanaan}

a. Pelaksanaan sosialisasi kepada kader PKK dusun Wonosuko (Sabtu, 10 Oktober 2020)

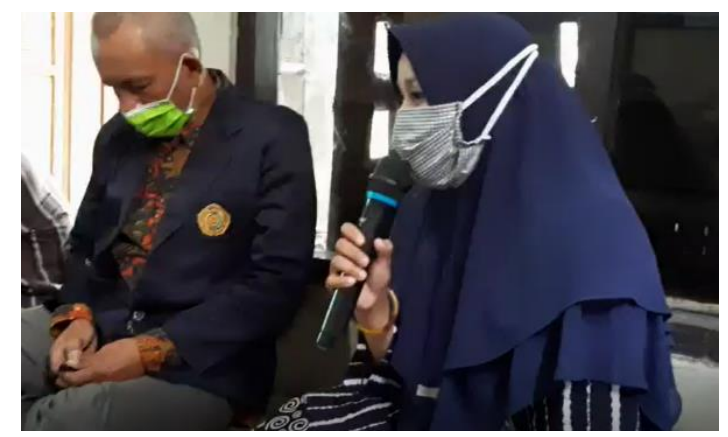

Gambar 1.Sambutan ketua PPMT ibu Ns.Estrin Handayani,S.Kep.,MAN

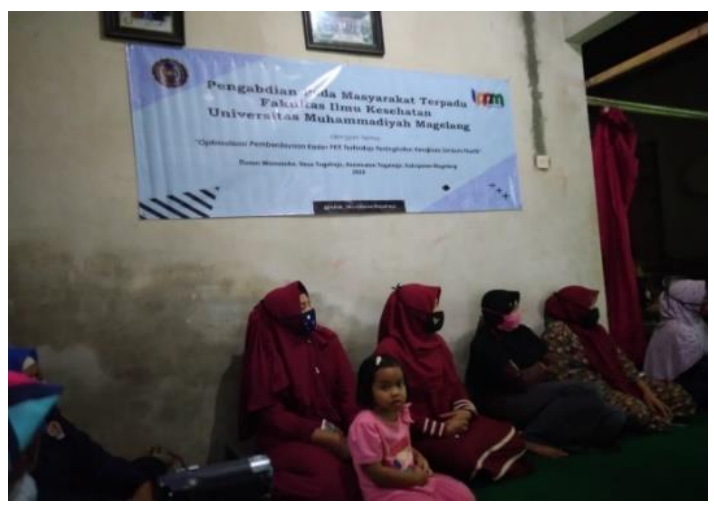

Gambar 2. Kader PKK dusun wonosuko mengikuti sosialisasi PPMT

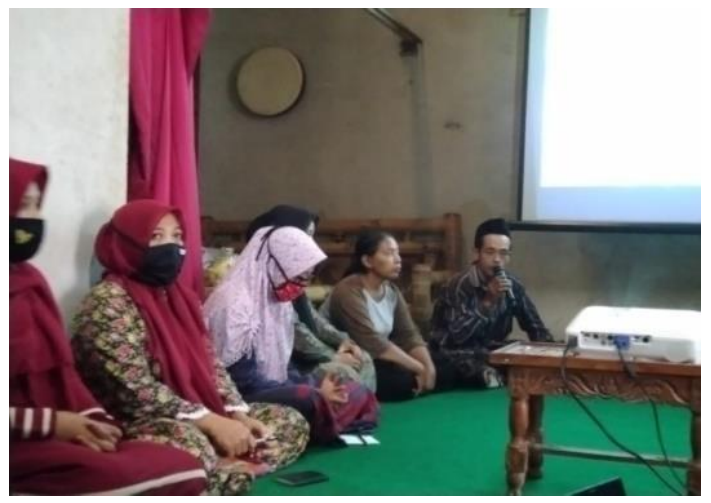

Gambar 3. Sambutan Kadus Wonosuko b. Sosialisasi Peningkatan Motivasi diri dalam berorganisasi oleh Bapak Rasidi, M.Pd (Sabtu, 17 Oktober 2020)

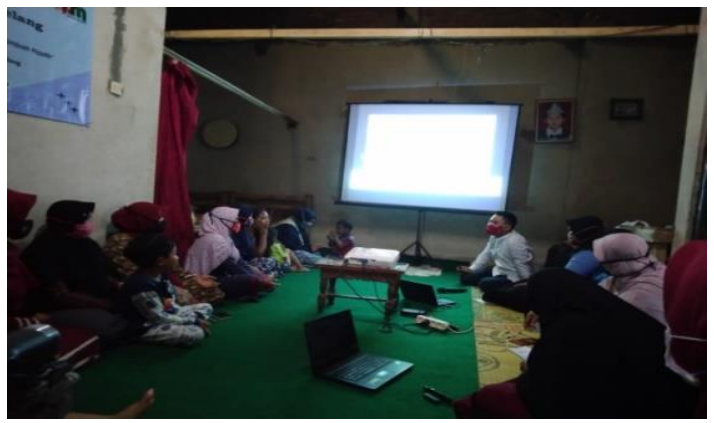

Gambar 4. Pengisian Materi oleh Rasidi, M.Pd

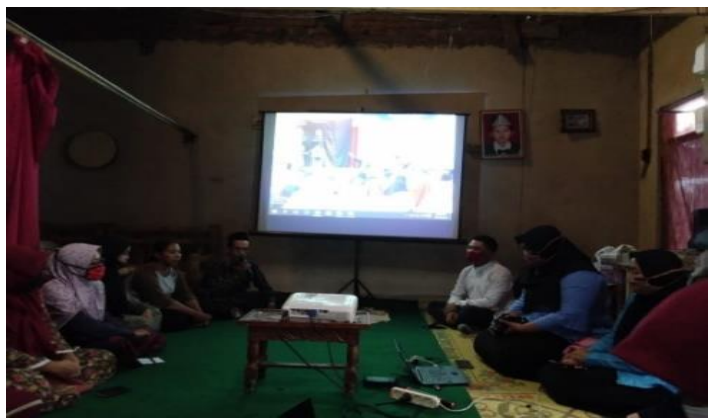

Gambar 5. Tanya jawab materi Rasidi, M.Pd

c. Penyuluhan Pengelolaan Limbah Sampah dari Dinas Lingkungan Hidup (DLH) Kabupaten Magelang oleh Ibu Sulastri (Sabtu, 17 Oktober 2020)

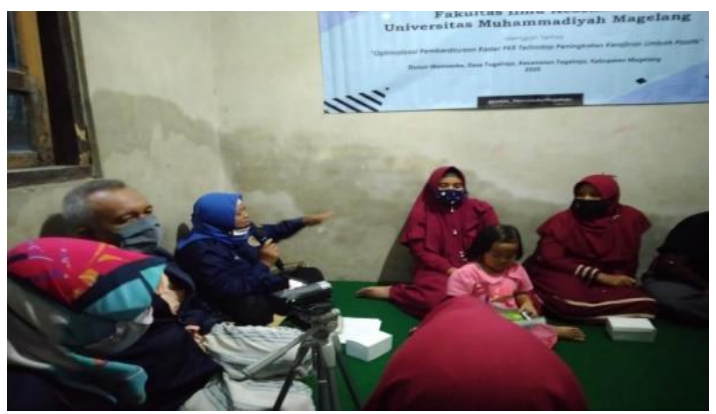

Gambar 6. Pengisian materi oleh ibu sulastri 


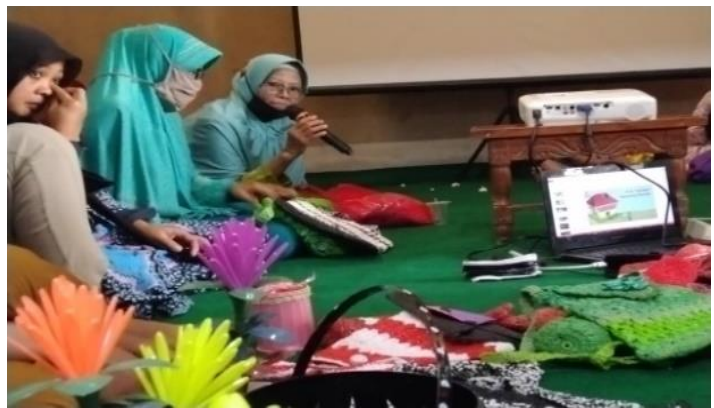

Gambar 7. Penjelasan cara membuat kerajinan dari limbah plastik

d. Praktek Pembuatan kerajinan berbahan baku limbah plastic oleh Kader PKK Dusun Wonosuko (Sabtu, 24 Oktober 2020)

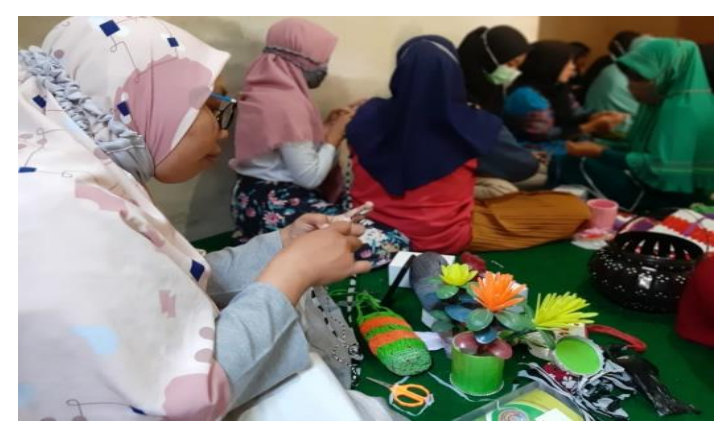

Gambar 8. PKK dusun wonosuko berlatih membuat kerajinan dari limbah plastik

\section{Pendampingan Mandiri}

Dalam tahap pendampingan mandiri selama 1 (satu) bulan di Dusun Wonosuko Tegalrejo Kabupaten Magelang terbentuk 3 kelompok kecil yang terdiri dari masing-masing kelompok 5 orang. Pembagian kelompok berdasarkan jenis kerajinan yang dibuat, adapun jenis kerajinan

kelompok 1: Rajut berbahan dasar limbah plastic kresek (berupa tas, tempat hp, tempat tumbler, connector masker, taplak meja, tempat tissue dll),

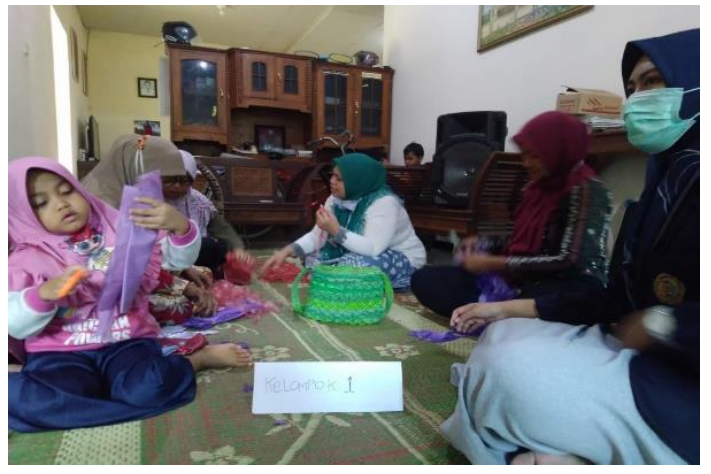

Gambar 9. PKK dusun wonosuko berlatih membuat kerajinan tas dari limbah plastik

kelompok 2: Bunga buatan berbahan dasar limbah plastic kresek (berupa aneka ragam jenis bunga),

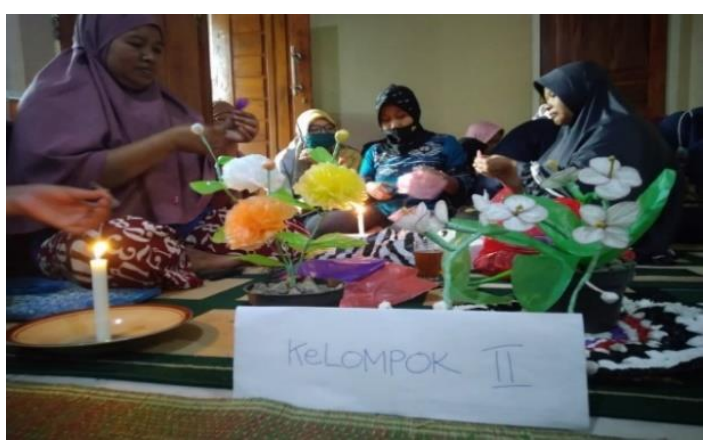

Gambar 10. PKK dusun wonosuko berlatih membuat kerajinan bunga dari limbah plastik

kelompok 3: Bunga berbahan dasar limbah sendok plastic (berupa jenis bunga).

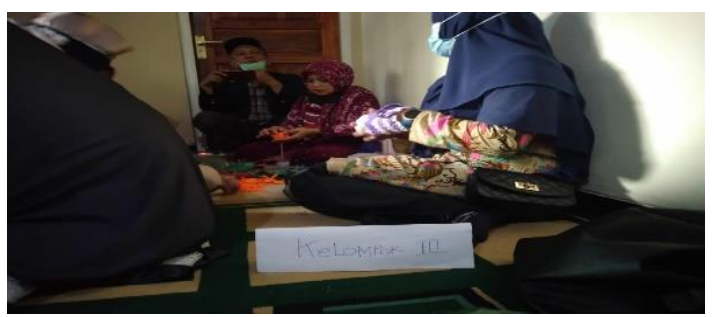

Gambar 11. PKK dusun wonosuko berlatih membuat kerajinan bunga dari limbah sendok plastik 


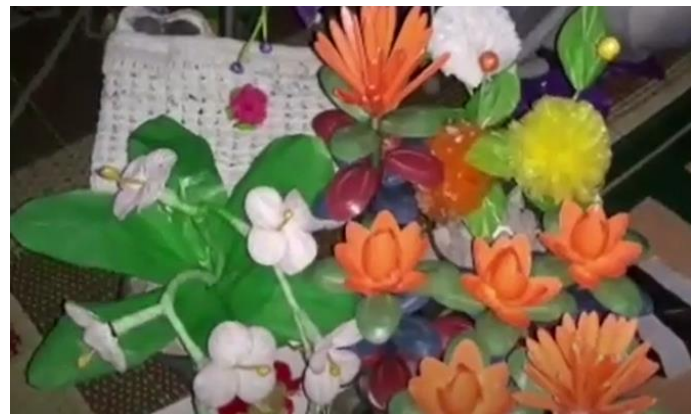

Gambar 11. Hasil kerajianan limbah plastik PKK dusun wonosuko

\section{Tindak Lanjut}

Kegiatan Pengabdian Pada

Masyarakat Terpadu (PPMT) ini mempunyai rencana tindak lanjut yang akan membantu Dusun Wonosuko mewujudkan Dusun Mandiri Sampah dengan membuat Pengelolaan Sampah Mandiri dengan mempunyai BANK SAMPAH.

Dasar pemikiran, Pemerintah Kabupaten Magelang melalui kebijakankebijakan terkait dengan kenyamanan lingkungan hidup, hal ini harus ada dukungan dan respon positif dari masyarakat untuk mendukung program atau kebijakan pemerintah terkait dengan menciptakan lingkungan yang sehat dan nyaman dan ikut andil dalam penanganan permasalahan terkait dengan lingkungan sekitar. Bentuk nyata yang bisa dilakukan oleh masyarakat untuk menciptakan lingkungan yang nyaman adalah dengan cara menjaga supaya lingkungan tidak kotor, tidak membuang sampah dengan sembarang atau bisa memanfaatkan sampah dengan cara dengan system $3 \mathrm{R}$ yaitu : Reduce (Mengurangi), Reuse (Menggunakan Kembali), dan Recycle (Mendaur Ulang).

Dalam UUP pun menghendaki semua pihak bergerak untuk mengolah sampah, sehingga nantinya sampah bukan hal yang menakutkan lagi, tapi memiliki sisi ekonomi dan manfaat (Roehaenah,
2019). Perintisan "BANK SAMPAH" dapat menjadi siasat dalam menyikapi permasalahan di sekitar lingkungannya dan berikutnya dapat sebagai kegiatan bersilaturahmi dan mempererat dalam berinteraksi, berkualitas dalam menciptakan lapangan pekerjaan serta mampu bersaing di era globalisasi seperti sekarang ini.

Setiap Dusun Wonosuko wajib berpartisipasi dalam program bank sampah ini dan seluruh nasabah bank sampah dapat mengantarkan sendiri sampahnya atau konfirmasi kepada pengurus bank sampah. Wilayah kerja bank sampah adalah diseluruh wilayah Dusun Wonosuko RW 8 desa Tegalrejo Kabupaten Magelang. Setiap nasabah wajib mendapatkan pembinaan dan penyuluhan oleh pengurus Bank sampah, Setiap nasabah harus memisahkan jenisjenis sampah yang telah di klasifikasikan. Sampah yang di setorkan kepada BANK telah di pisahkan sesuai dengan jenisjenisnya.

Sampah yang terkumpul di Bank Sampah akan di olah kembali oleh pengurus atau di alihkan serta di jual kembali oleh pihak lain yang telah bekerjasama dengan pihak bank sampah . Setiap industri yang berdomisili di kewilayahan dusun Wonosuko untuk mendistribusikan sampah/limbah yang dapat di manfaatkan kepada bank sampah dan setiap sampah yang di hasilkan di wilayah Dusun Wonosuko adalah tanggung jawab Pengurus Bank sampah. Pihak pengurus berhak menegur, serta memberikan sanksi kepada masyarakat /daerah yang masih membuang sampah sembarangan, Setiap sampah yang tidak bisa di olah atau sampah yang pantas untuk di buang maka sampah akan di angkut ke tempat pembuangan akhir (TPA). Setiap sampah yang akan di buang ke TPA akan di angkut oleh mobil 
Jurdimas (Jurnal Pengabdian Kepada Masyarakat) Royal

Vol. 4 No. 2, Mei 2021, hlm. 173 - 180

ISSN 2614-7912 (Print)

DOI: https://doi.org/10.33330/jurdimas.v4i2.955

ISSN 2622-3813 (Online)

Available online at https://jurnal.stmikroyal.ac.id/index.php/jurdimas

dinas kebersihan dan pertamanan.

\section{SIMPULAN}

Program Pengabdian Pada Masyarakat Terpadu (PPMT) melalui Tim Penggerak PKK Dusun Wonosuko RW 8 desa Tegalrejo kabupaten Magelang merupakan harapan masyarakat khususnya seluruh warga dalam menyikapi permasalahan di lingkungan sekitar, mengingat permasalahan yang di anggap cukup serius bagi kepentingan bersama, semua yang akan kami tuangkan dalam program ini sekiranya kegiatan yang sangat bermanfaat untuk kehidupan.

Baik dalam penanganan masalah pemanasan global, maupun dalam penanganan resiko-resiko yang dapat dihasilkan dari sampah-sampah di sekitar, yang belakangan ini sering diremehkan keberadaannya padahal resiko yang terkandung didalamnya sangat membahayakan bagi kehidupan. Minimal program ini menjadi bukti bahwa pemuda dan pemudi yang telah berkomitmen dalam program ini mencoba melakukan hal positif yang dapat bermanfaat bagi agama, nusa, dan bangsa.

\section{DAFTAR PUSTAKA}

Filmawada, Z., Hardika, H., \& Sucipto, S. (2018). Peran Kader Pkk Sebagai Agen Perubahan Kebersihan Dan Kesehatan Lingkungan Melalui Pendampingan Program Bank Sampah. Jurnal Pendidikan Nonformal, 13(2), 78-84.

Natalia, L., Wihardja, H., \& Ningsih, P. W. (2021). Pendampingan
Pengelolaan Sampah Terpadu Berbasis Masyarakat dengan Konsep 3R Di desa Sukaluyu. Jurdimas (Jurnal Pengabdian Kepada Masyarakat) Royal, 4(1), 21-26.

Rodiah, Lusiana, \& Agustine. (2016). Pemberdayaan Kader Pkk Dalam Usaha Penyebarluasan Informasi Kesehatan Jatinangor. Jurnal Aplikasi Ipteks Untuk Masyarakat, 5(1), 34-37. Retrieved From Journdharmakarya/Article/Viewfil e/11437/5233al.Unpad.Ac.Id/

Roehaenah. (2019). Evaluasi Rencana Kerja Pembangunan Daerah Kabupaten Indaramayu. Jurnal Ilmu Administrasi Reformasi, 1(4), 39-50.

Setianingsih, B., Setyowati, E., \& Siswidiyanto, S. (2019). Efektivitas Sistem Perencanaan Pembangunan Daerah (Simrenda) (Studi Pada Badan Perencanaan Pembangunan Daerah Kabupaten Balangan). Jurnal Administrasi Publik (Jap), 3(11), 87-101.

Sugiarto, A., \& Mutiarin, D. (2017). Konsistensi Perencanaan Pembangunan Daerah Dengan Anggaran Daerah. Journal of Governance And Public Policy, 4(1), 1-38. Https://Doi.Org/10.18196/Jgpp.41 70

Vuspitasari, B. K., Deffrinica, D., Siahaan, S. V. B., \& Novita, N. (2021). Pemberdayaan Perempuan dalam Memanfaatkan Sampah Kresek Menjadi Produk Bernilai Ekonomis. Jurdimas (Jurnal Pengabdian Kepada Masyarakat) Royal, 4(1), 33-38. 